\title{
Wykorzystanie strategii innowacyjnych opartych na ksztaltowaniu społeczeństwa informacyjnego w procesie poprawy konkurencyjności przedsiębiorstwa - na przykładzie przedsiębiorstw z grupy MŚP z branży przemysłu metalowego
}

Jednym z głównych celów budowy gospodarki opartej na wiedzy jest kształtowanie społeczeństwa informacyjnego. Znaczenie innowacji dla tego procesu jest niezwykle istotne - zwłaszcza dla przedsiębiorstw działających w warunkach nasilonej konkurencji. Czynniki wpływające na poprawę innowacyjności przedsiębiorstw, w tym przedsiębiorstw $\mathrm{z}$ grupy MŚP, powinny być szczególnie akcentowane. Na przykładzie firm z branży przemysłu metalowego możliwa jest identyfikacja elementów procesu kształtowania społeczeństwa informacyjnego, a następnie konstruowanie strategii innowacyjnych w celu poprawy konkurencyjności przedsiębiorstw

Współczesne przedsiębiorstwa dążą do osiągnięcia przewagi konkurencyjnej, starając się zdobyć jak najszerszą wiedzę o rynku i jego uczestnikach. Pozyskanie takich informacji pozwala na przewartościowanie zasobów przedsiębiorstwa, sformułowanie nowych celów rynkowych i sformułowanie strategii rynkowej. Jest to proces ciągły, którego dynamika świadczy o zdolności przedsiębiorstwa do szybkich reakcji na sygnały płynące z rynku oraz dostosowania się do potrzeb rynku. Można zatem sformułować istotne cechy społeczeństwa informacyjnego - w powiązaniu $\mathrm{z}$ rynkową orientacją przedsiębiorstwa, które zamierza poprawiać swoją konkurencyjność.

\section{Cechy społeczeństwa informacyjnego ${ }^{1}$}

1. Wytwarzanie informacji - o masowym charakterze, jako reakcja na masowe zapotrzebowanie na wiedzę oraz udostępnienie ich do powszechnego i masowego wykorzystywania.

2. Przechowywanie informacji - zapewnienie technicznych możliwości tworzenia baz danych istotnych do funkcjonowania przedsiębiorstwa na rynku oraz umożliwienie dostępu do nich.

3. Przetwarzanie informacji - budowa systemu informacyjnego właściwego dla określonego sektora przemysłu, przedsiębiorstwa czy grupy przedsiębiorstw ${ }^{2}$.

4. Przekazywanie informacji do adresatów lub tworzenie przekazu ogólnodostępnego, bez względu na czas i przestrzeń.

\footnotetext{
${ }^{1} \mathrm{~W}$ literaturze przedmiotu można wskazać wiele definicji i opinii na temat cech społeczeństwa informacyjnego. Są one uaktualniane wraz z rozwojem ekonomicznym i gospodarczym społeczeństw (włączając obecne teorie zrównoważonego rozwoju).

${ }^{2}$ Konieczność budowy systemu informacji jako elementu niezbędnego do przyspieszenia transferu wiedzy sfery $\mathrm{B}+\mathrm{R}$ do sfery przemysłowej została przedstawiona m.in. w publikacji L. Białoń i D. Janczewskiej Marketingowe wsparcie procesów innowacyjnych, Postępy Techniki Przetwórstwa Spożywczego, 1/2005, s. 72.
} 
5. Pobieranie informacji - możliwość odbierania informacji przez wszystkich zainteresowanych, z uwzględnieniem ograniczeń wynikających z regulacji prawnych lub przepisów wewnętrznych przedsiębiorstwa.

6. Wykorzystywanie informacji - powszechne, otwarte i nielimitowane korzystanie z internetu jako źródła informacji, z uwzględnieniem zagadnień dotyczących ochrony własności intelektualnej.

7. Posługiwanie się różnorodnymi formami informacji podczas realizacji działań z zakresu ochrony środowiska przyrodniczego, z zachowaniem zasad zrównoważonego rozwoju w danym sektorze gospodarki.

Kształtowanie się społeczeństwa informacyjnego - na podstawie badań przedsiębiorstw Merytoryczna treść informacji niezbędnych do realizacji procesu reagowania na sygnały z otoczenia przedsiębiorstwa i umiejętność formułowania strategii rynkowych (strategii marketingowych) są ściśle powiązane z poziomem zdolności przedsiębiorstwa do zdobywania informacji o rynku. Obecny szybki rozwój techniki informatycznych daje taką możliwość i powoduje ogromne przyspieszenie, a zatem i skrócenie czasu niezbędnego do stworzenia bazy danych, ich przetworzenia, a następnie sformułowania strategii firmy. Przedsiębiorstwa, które starają się osiągać odpowiednią pozycję rynkową, powinny wykorzystywać możliwości techniki informatycznej wspomagającej podejmowanie decyzji o kluczowym znaczeniu dla rozwoju firmy.

We współczesnych badaniach podkreśla się znaczenie informacji, które stały się produktem $^{3}$, pojawiły się banki informacji, możemy mówić o zarządzaniu informacją oraz adresowaniem informacji do właściwego odbiorcy - z wykorzystaniem komputerów.

W tab. 1 przedstawione zostały wyniki badań dotyczących liczby pracowników wykorzystujących w swojej pracy komputery, w zależności od wielkości przedsiębiorstwa Z badań wynika, że ogółem jedynie 33-38\% pracowników w polskich firmach korzysta z komputera (przynajmniej raz w tygodniu ), z czego tylko 21-28\% ma dostęp do internetu. Stosunkowo najlepiej wskazania procentowe określają liczbę korzystających z komputerów w dużych przedsiębiorstwach, a przedsiębiorstwa z grupy MŚP charakteryzują się niskimi wskazaniami wykorzystania komputerów.

Tab. 1. Udział pracowników wykorzystujących komputery w przedsiębiorstwach według wielkości w latach 2004-2006 (w \%)

\begin{tabular}{|c|c|c|c|c|c|c|}
\hline \multirow{2}{*}{ Przedsiębiorstwa } & \multicolumn{3}{|c|}{ Ogółem } & \multicolumn{2}{c|}{ W tym z dostępem do internetu } \\
\cline { 2 - 7 } & $\mathbf{2 0 0 4}$ & $\mathbf{2 0 0 5}$ & $\mathbf{2 0 0 6}$ & $\mathbf{2 0 0 4}$ & $\mathbf{2 0 0 5}$ & $\mathbf{2 0 0 6}$ \\
\hline Małe & 33 & 36 & 36 & 22 & 27 & 29 \\
\hline Średnie & 31 & 35 & 35 & 21 & 26 & 27 \\
\hline Duże & 36 & 42 & 45 & 21 & 28 & 28 \\
\hline
\end{tabular}

Jak wynika z badań prezentowanych w tab.1 oraz na ryc. 2, odnotowuje się stosunkowo niskie wykorzystanie możliwości informacyjnych, jakie daje komputer oraz dostęp do internetu w przetwórstwie przemysłowym. W roku 2006 tylko 29\% osób zatrudnionych w przemyśle

\footnotetext{
${ }^{3}$ Można założyć, że informacja - jako towar - może być analizowana na gruncie marketingu. Można wówczas mówić o instrumentach dotyczących informacji jako produktu, ceny informacji, dystrybucji informacji, promocji informacji.
} 
korzystało z internetu przynajmniej 1 raz w tygodniu. Wynika to niechętnej postawy właścicieli małych firm wobec wykorzystywania komputerów i obawy przed utratą danych (na skutek działań niepowołanych osób lub firm). Porównując dane liczbowe dotyczące wykorzystania komputerów i internetu w przedsiębiorstwach w Polsce $\mathrm{z}$ analogicznymi danymi dotyczącymi krajów Unii Europejskiej ogółem, można wyraźnie stwierdzic różnicę wskazań pomiędzy Polską a liderem - Danią - co przedstawia tab. 2.

Tab. 2. Porównanie wskaźników dotyczących korzystania z komputerów i internetu w Polsce i wybranych krajach UE

\begin{tabular}{|c|c|c|c|c|}
\hline Wyszczególnienie & Polska & Unia-25 & Dania & Bulgaria \\
\hline $\begin{array}{l}\text { Pracownicy wykorzystujący } \\
\text { komputery (w \%) }\end{array}$ & 38 & 51 & 68 & 22 \\
\hline $\begin{array}{l}\text { w tym z dostępem } \\
\text { do internetu }\end{array}$ & 28 & 36 & 62 & 15 \\
\hline
\end{tabular}

Źródło: opracowanie autorki na podstawie danych Eurostatu i Społeczeństwo informacyjne w Polsce. Wyniki badań statystycznych, GUS, Warszawa 2008, s. 73.

Czy zatem możemy obecnie mówić o kształtowaniu społeczeństwa informacyjnego w polskich przedsiębiorstwach, które mają zbyt mało instrumentów służących do zdobywania informacji, ich przetwarzania i przekazywania, a ich pracownicy niechętnie wykorzystują komputery $\mathrm{i}$ internet.

Na ryc. 2 porównano procentowe wskaźniki wykorzystania współczesnych narzędzi informacyjnych w Polsce i w wybranych krajach Unii Europejskiej (25 krajów). Jest to jednocześnie wskaźnik poziomu luki technologicznej w tym obszarze.

Ryc. 2. Udział pracowników korzystających z komputerów i internetu w wybranych krajach Unii Europejskiej

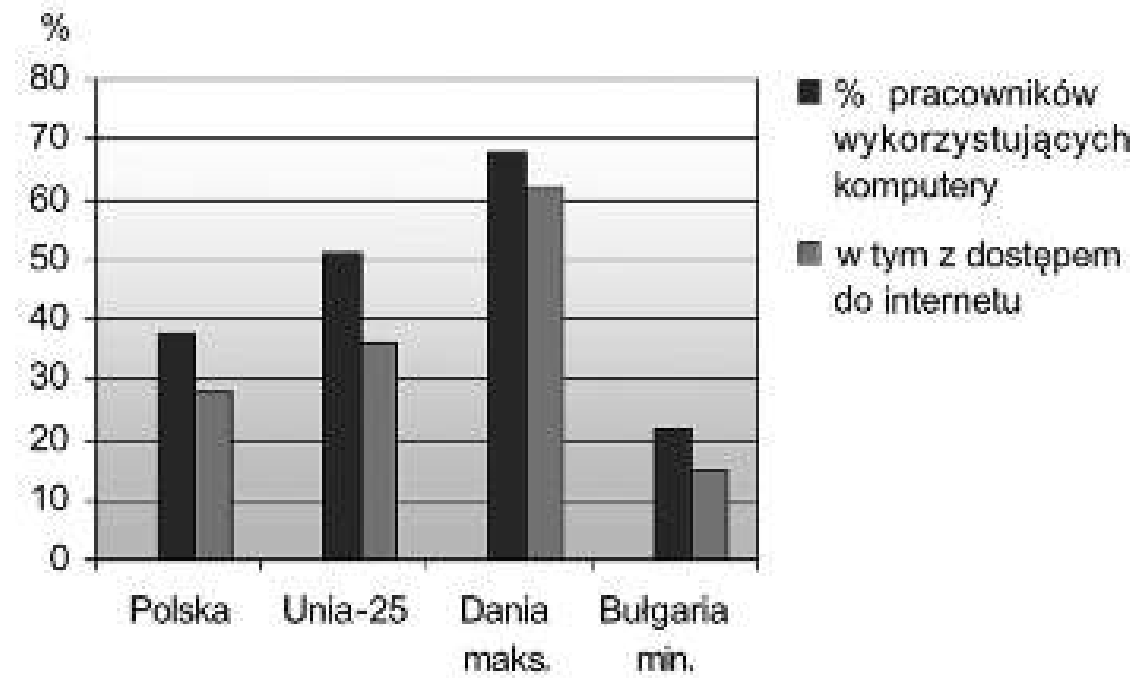

Źródło: opracowanie autorki na podstawie danych Eurostatu.

\section{Przedsiębiorstwa produkcyjne z grupy MŚP w przemyśle metalowym w Polsce}

W przemyśle metalowym w Polsce obserwuje się nasilenie działań konkurencyjnych, podobnie jak $\mathrm{w}$ innych sektorach gospodarki. Taka sytuacja wynika $\mathrm{z}$ rosnącego zapotrzebowania na konstrukcje stalowe zarówno w innych gałęziach przemysłu w Polsce (głównie przemysłu maszynowego i budownictwa), ale także ze wzrostu eksportu do krajów Unii Europejskiej oraz do innych krajów. Dynamika produkcji sprzedanej w przemyśle metalowym (elementów konstrukcyjnych) 
w Polsce została przedstawiona na ryc. 3. Z danych GUS wynika, że w latach 1996-2006 wartość produkcji sprzedanej wzrosła prawie 6-krotnie. W latach 2000-2002, przyjmując za kryterium osiągnięte wyniki finansowe, wystąpiła stagnacja w tej branży, ale od roku 2003 wystąpił kolejny skokowy wzrost wartości sprzedaży. Taka wartość i dynamika wzrostu rynku konstrukcji stalowych wskazują na jego wysoką konkurencyjność ${ }^{4}$. Rynek producentów konstrukcji stalowych jest jednak rozdrobniony; działa na nim ponad 300 firm zatrudniających ponad 50 osób $^{5}$. Szacuje się, że produkcja konstrukcji stalowych wyniosła w roku 2007 około 790 tys. ton. Polska jest więc jednym z głównych producentów konstrukcji stalowych w Europie ${ }^{6}$.

Ryc. 3. Produkcja sprzedana w branży metalowej (konstrukcje stalowe) w latach 1996-2006

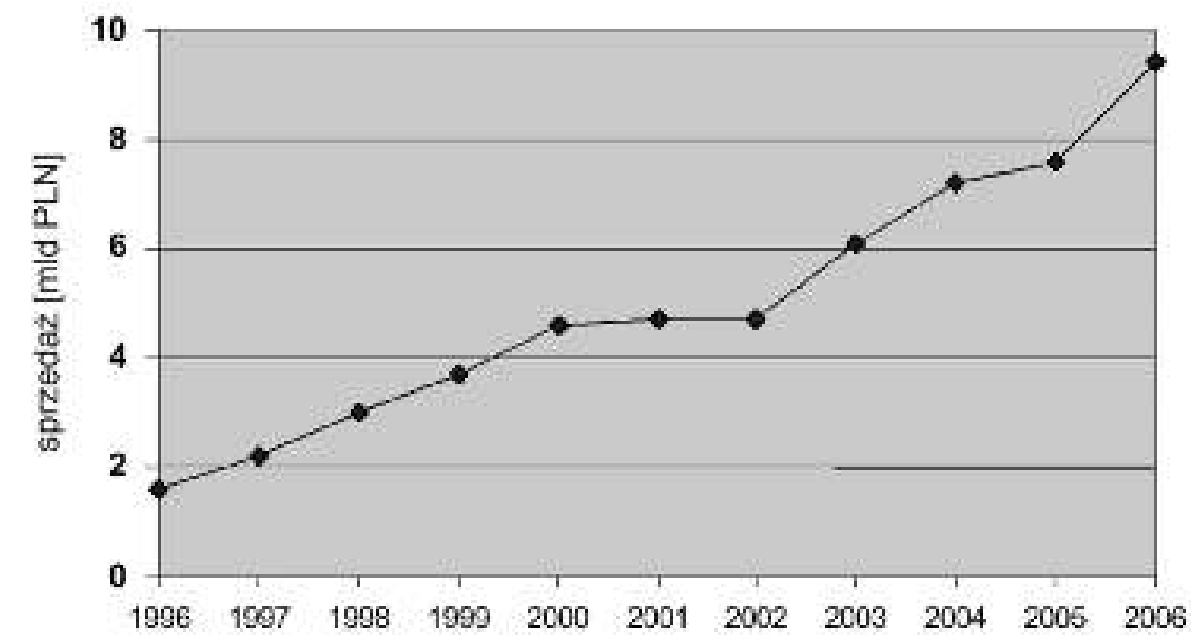

Źródło: opracowanie autorki na podstawie biuletynu GUS Nakłady i wyniki przemysłu.

Z analizy danych GUS dotyczących branży wynika, że dynamika wzrostu sprzedaży i produkcji kształtuje się na poziomie $20-30 \%$ w relacji rok bieżący do roku poprzedniego, co zostało pokazane w tab. 3 .

Tab. 3. Podstawowe wskaźniki charakteryzujące branżę konstrukcji stalowych w Polsce w latach 2003-2007

\begin{tabular}{|l|r|r|r|r|r|}
\hline \multicolumn{1}{|c|}{ Wyszczególnienie } & $\mathbf{2 0 0 3}$ & $\mathbf{2 0 0 4}$ & $\mathbf{2 0 0 5}$ & $\mathbf{2 0 0 6}$ & $\mathbf{2 0 0 7}$ \\
\hline $\begin{array}{l}\text { Produkcja sprzedana w mln zł w cenach bieżących } \\
\text { (w zakładach > 49 osób) }\end{array}$ & 6088 & 7232 & 7587 & 9374 & 12510 \\
\hline Wzrost produkcji w cenach stałych; rok poprzedni =100 & 127,5 & 114,1 & 107,5 & 122,9 & 128,3 \\
\hline Rentowność netto w budownictwie w \% & $-0,6$ & 1,1 & 1,7 & 3,5 & 4,9 \\
\hline $\begin{array}{l}\text { Rentowność netto producentów metalowych } \\
\text { elementów konstrukcyjnych w \% }\end{array}$ & 2,5 & 4,4 & 5,1 & 6,1 & 6,1 \\
\hline $\begin{array}{l}\text { Ceny produkcji sprzedanej wyrobów metalowych; } \\
\text { rok poprzedni = 100 }\end{array}$ & 101,7 & 104,3 & 98,3 & 101,2 & 102,6 \\
\hline $\begin{array}{l}\text { Ceny produkcji sprzedanej wyrobów hutniczych; } \\
\text { rok poprzedni = 100 }\end{array}$ & 107,7 & 127,8 & 96,3 & 110,5 & 107,4 \\
\hline
\end{tabular}

Źródło: Nakłady i wyniki przemysłu, Biuletyn Statystyczny GUS, 2004-2008.

\footnotetext{
${ }^{4}$ Szerzej na temat sektora konstrukcji stalowych spawanych w publikacji: D. Janczewska, Podnoszenie konkurencyjności firm z grupy MŚP w branży konstrukcji spawanych, „STAL-Metale\&Nowe Technologie”, $11-12 / 2008$, s. 21.

${ }^{5}$ Zakłady zatrudniające ponad 50 osób podlegają sprawozdawczości GUS, znane są zatem ich liczba oraz wskaźniki gospodarcze.

${ }^{6}$ Rynek konstrukcji stalowych, „Branżowy Informator Gospodarczy 2007”, 10.12.2007 r.
} 
Wysoki wolumen produkcji i sprzedaży konstrukcji stalowych w Polsce stawia nasz przemysł na czwartym miejscu wśród krajów Unii Europejskiej. Dane liczbowe z roku 2005 stawiają polski przemysł metalowy (produkcję konstrukcji stalowych) przed Francją, Holandią i wieloma innymi krajami UE. Ryc. 4 przedstawia wielkość produkcji konstrukcji stalowych w krajach UE.

Ryc. 4. Produkcja konstrukcji stalowych w krajach Unii Europejskiej w 2005 r.

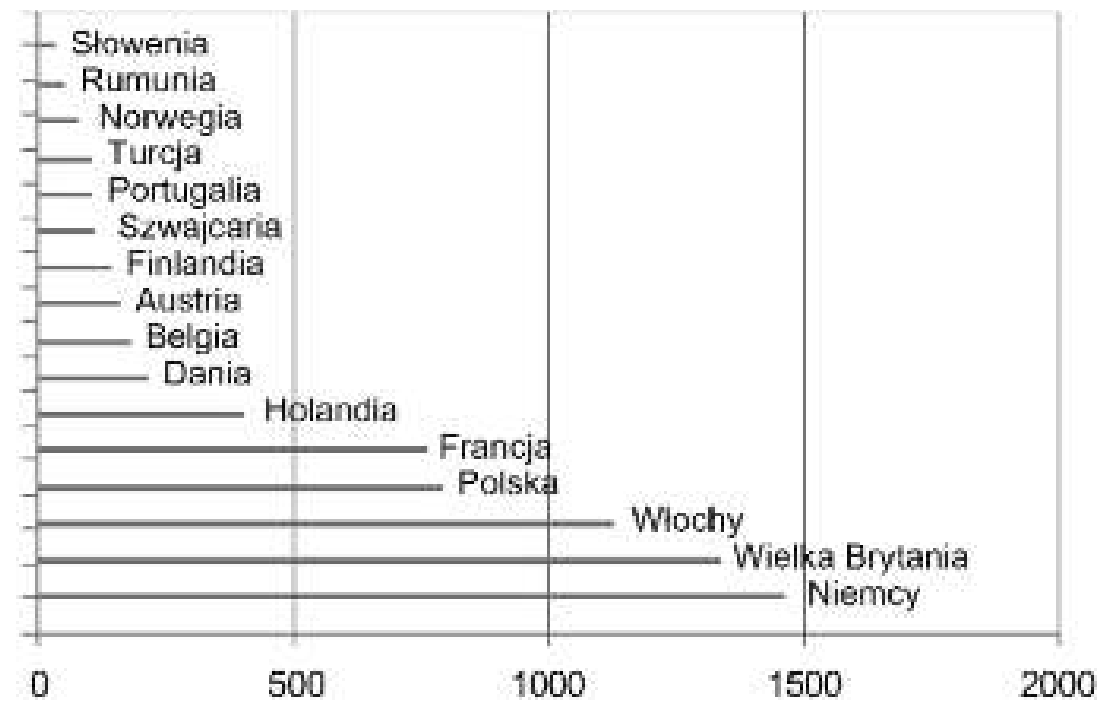

Źródło: opracowanie autorki na podstawie danych Eurostatu.

Brak jest bliższych danych statystycznych oraz informacji o kondycji małych przedsiębiorstw produkujących konstrukcje stalowe. W zasadzie nie mogą one konkurować z dużymi firmami, zatrudniającymi po kilkaset osób, wyposażonymi w wysoko wydajne maszyny, technologie itd. MŚP mogą natomiast konkurować $\mathrm{z}$ dużymi firmami w obszarze szybkości zdobywania informacji i reagowania na potrzeby klientów. Obserwacje autorki prowadzone w wybranych przedsiębiorstwach produkcyjnych $\mathrm{z}$ grupy MŚP $\mathrm{w}$ przemyśle metalowym ${ }^{7}$ potwierdzają cytowane opracowania GUS dotyczące słabego wykorzystania posiadanych urządzeń - instrumentów wspomagających przepływ informacji. Cechy społeczeństwa informacyjnego występujące w wybranych firmach zaprezentowano w tab. 3. Na podstawie obserwacji można wskazać istotne cechy potwierdzające proces budowy społeczeństwa informacyjnego oraz ich wpływ na rozwój przedsiębiorstw.

Tab. 3. Przykłady cech społeczeństwa informacyjnego w grupie wybranych przedsiębiorstw produkcyjnych MŚP w przemyśle metalowym

\begin{tabular}{|c|c|l|l|c|}
\hline Lp. & Cecha & $\begin{array}{c}\text { Atrybuty - cechy } \\
\text { spoleczeństwa } \\
\text { informacyjnego }\end{array}$ & $\begin{array}{c}\text { Przykłady występowania } \\
\text { atrybutów w przedsiębiorstwie } \\
\text { z grupy MŚP premyslu } \\
\text { metalowego }\end{array}$ & $\begin{array}{c}\text { Wskazanie \%o } \\
\text { pozytywnych } \\
\text { odpowiedzi } \\
\text { dotyczących } \\
\text { danej cechy }\end{array}$ \\
\hline 1. & $\begin{array}{l}\text { Wytwarzanie } \\
\text { informacji }\end{array}$ & $\begin{array}{l}\text { masowy charakter } \\
\text { generowanych } \\
\text { informacji, masowe } \\
\text { zapotrzebowanie na } \\
\text { informację i masowy } \\
\text { sposób wykorzystywania } \\
\text { informacji }\end{array}$ & $\begin{array}{l}\text { Informacje niezbędne } \\
\text { w przedsiębiorstwie: } \\
\text { dane o rynku, informacje } \\
\text { o otoczeniu } \\
\text { poszukiwanie informacji } \\
\text { o nowych technologiach, } \\
\text { technikach }\end{array}$ & 30 \\
\hline
\end{tabular}

\footnotetext{
${ }^{7}$ Badania własne prowadzone w ramach PW-004/01/2006/2/UW-2006 pt. Metodyka transformacji wyników badań naukowych do zastosowań praktycznych oraz PW-004/ITE/01/2006 pt. Rozwój metod transformacji wiedzy i transferu technologii dotyczą wybranych przedsiębiorstw produkcyjnych z grupy MŚP z województw: łódzkiego, mazowieckiego i kujawsko-pomorskiego.
} 


\begin{tabular}{|c|c|c|c|c|}
\hline Lp. & Cecha & $\begin{array}{l}\text { Atrybuty - cechy } \\
\text { spoleczeństwa } \\
\text { informacyjnego }\end{array}$ & $\begin{array}{c}\text { Przyklady występowania } \\
\text { atrybutów w przedsiębiorstwie } \\
\text { z grupy MŚP przemysłu } \\
\text { metalowego }\end{array}$ & $\begin{array}{r}\text { Wskazanie \% } \\
\text { pozytywnych } \\
\text { odpowiedzi } \\
\text { dotyczących } \\
\text { danej cechy }\end{array}$ \\
\hline $\begin{array}{c}1 . \\
(\text { dok. })\end{array}$ & $\begin{array}{l}\text { Wytwarzanie } \\
\text { informacji }\end{array}$ & & $\begin{array}{l}\text { - informacje o nowych narzędziach } \\
\text { - informacje o środkach ochrony } \\
\text { pracowników } \\
\text { - informacje o trendach } \\
\text { w produkcji w branży } \\
\text { - informacje w skali Europy } \\
\text { i świata }\end{array}$ & $\begin{array}{l}40 \\
60 \\
20 \\
30\end{array}$ \\
\hline 2. & $\begin{array}{l}\text { Przechowywanie } \\
\text { informacji }\end{array}$ & $\begin{array}{l}\text { techniczne } \\
\text { możliwości } \\
\text { gromadzenia } \\
\text { i nieograniczonego } \\
\text { magazynowania } \\
\text { informacji }\end{array}$ & $\begin{array}{l}\text { Przedsiębiorstwo: } \\
\text { - posiada wystarczającą liczbę } \\
\text { komputerów } \\
\text { - ma sieć wewnętrzną } \\
\text { - ma dostęp do internetu } \\
\text { - tworzy bazy danych }\end{array}$ & $\begin{array}{l}50 \\
20 \\
50 \\
20\end{array}$ \\
\hline 3. & $\begin{array}{l}\text { Przetwarzanie } \\
\text { informacji }\end{array}$ & $\begin{array}{l}\text { opracowywanie } \\
\text { technologii } \\
\text { i standardów } \\
\text { umożliwiających } \\
\text { m.in. ujednolicony } \\
\text { opis i wymianę } \\
\text { informacji }\end{array}$ & $\begin{array}{l}\text { - Przedsiębiorstwo ma odpowiednio } \\
\text { wykwalifikowanych } \\
\text { pracowników, zainteresowanych } \\
\text { uzyskaniem i wymianą informacji. } \\
\text { - Zakres współpracy informacyjnej } \\
\text { wynika ze struktury organizacji } \\
\text { oraz procesów wewnątrz firmy. }\end{array}$ & $\begin{array}{l}60 \\
60\end{array}$ \\
\hline 4. & $\begin{array}{l}\text { Przekazywanie } \\
\text { informacji }\end{array}$ & $\begin{array}{l}\text { przekazywanie } \\
\text { informacji bez } \\
\text { względu na czas } \\
\text { i przestrzeń }\end{array}$ & $\begin{array}{l}\text { - Wymiana informacji pomiędzy } \\
\text { pracownikami firmy oraz } \\
\text { przekazywanie odpowiednich } \\
\text { przetworzonych informacji na } \\
\text { zewnątrz nie są ograniczone } \\
\text { czasem i przestrzenią. }\end{array}$ & 30 \\
\hline 5. & $\begin{array}{l}\text { Pobieranie } \\
\text { informacji }\end{array}$ & $\begin{array}{l}\text { możliwość odbierania } \\
\text { informacji przez } \\
\text { wszystkich } \\
\text { zainteresowanych }\end{array}$ & $\begin{array}{l}\text { Przepływ informacji pomiędzy } \\
\text { zainteresowanymi nie jest } \\
\text { ograniczony czasem } \\
\text { i przestrzenią. }\end{array}$ & 20 \\
\hline 6. & $\begin{array}{l}\text { Wykorzystywanie } \\
\text { informacji }\end{array}$ & $\begin{array}{l}\text { powszechne, otwarte } \\
\text { i nielimitowane } \\
\text { korzystanie } \\
\text { z internetu jako } \\
\text { źródła informacji }\end{array}$ & $\begin{array}{l}\text { Informacje są wykorzystywane we } \\
\text { wszystkich strukturach przedsię- } \\
\text { biorstwa: } \\
\text { - w zarządzaniu zasobami ludzkimi } \\
\text { - w księgowości } \\
\text { - w przyjmowaniu zamówień od } \\
\text { klientów } \\
\text { - w planowaniu i dokonywaniu } \\
\text { zakupów } \\
\text { - w prowadzeniu dokumentacji } \\
\text { procesów produkcyjnych }\end{array}$ & $\begin{array}{l}20 \\
70 \\
50 \\
30 \\
20\end{array}$ \\
\hline
\end{tabular}

Źródło: opracowanie autorki na podstawie badań własnych.

Tylko część firm z grupy MŚP w przemyśle metalowym poszukuje informacji związanych z prowadzoną działalnością. Firmy te rzadko sięgają po informacje o swoich konkurentach 
i kooperantach (30\% wskazań).Wynika to z nieznajomości korzyści z szybkiego dostępu do źródeł informacji oraz jego istotnego wpływu na wyniki przedsiębiorstwa. Jedynie 1/5 badanych firm posiada wewnętrzną sieć (intranet), umożliwiającą przyspieszenie przepływu informacji wewnątrz przedsiębiorstwa. Firmy zagraniczne wykazywały pełne zainteresowanie wytwarzaniem informacji, ich przechowywaniem i przetwarzaniem. $Z$ danych uzyskanych $w$ firmach $z$ kapitałem zagranicznym wynika, że komputery, sieć wewnętrzna i internet są codziennym, zwykłym narzędziem menedżerów i kierowników komórek organizacyjnych. Z odpowiedzi badanych menedżerów wynika, że widzą oni bardzo silną zależność pomiędzy stosowaniem komputerów oraz technologii informacyjnych a wynikami przedsiębiorstwa i jego rozwojem. Bazy danych, które tworzą małe przedsiębiorstwa branży produkującej konstrukcje metalowe, powinny stać się podstawą opracowania zestawień dla właścicieli, zarządów, podejmujących decyzje istotne dla przedsiębiorstwa. Model systemu przepływu informacji do ośrodków podejmujących kluczowe decyzje o znaczeniu strategicznym dla małego przedsiębiorstwa - na przykładzie przedsiębiorstwa z grupy MSP w przemyśle metalowym - został pokazany na ryc. 5 .

Ryc. 5. Model systemu dopływu (wyszukiwania) informacji niezbędnych do podejmowania kluczowych decyzji w przedsiębiorstwie z grupy MSP w przemyśle metalowym

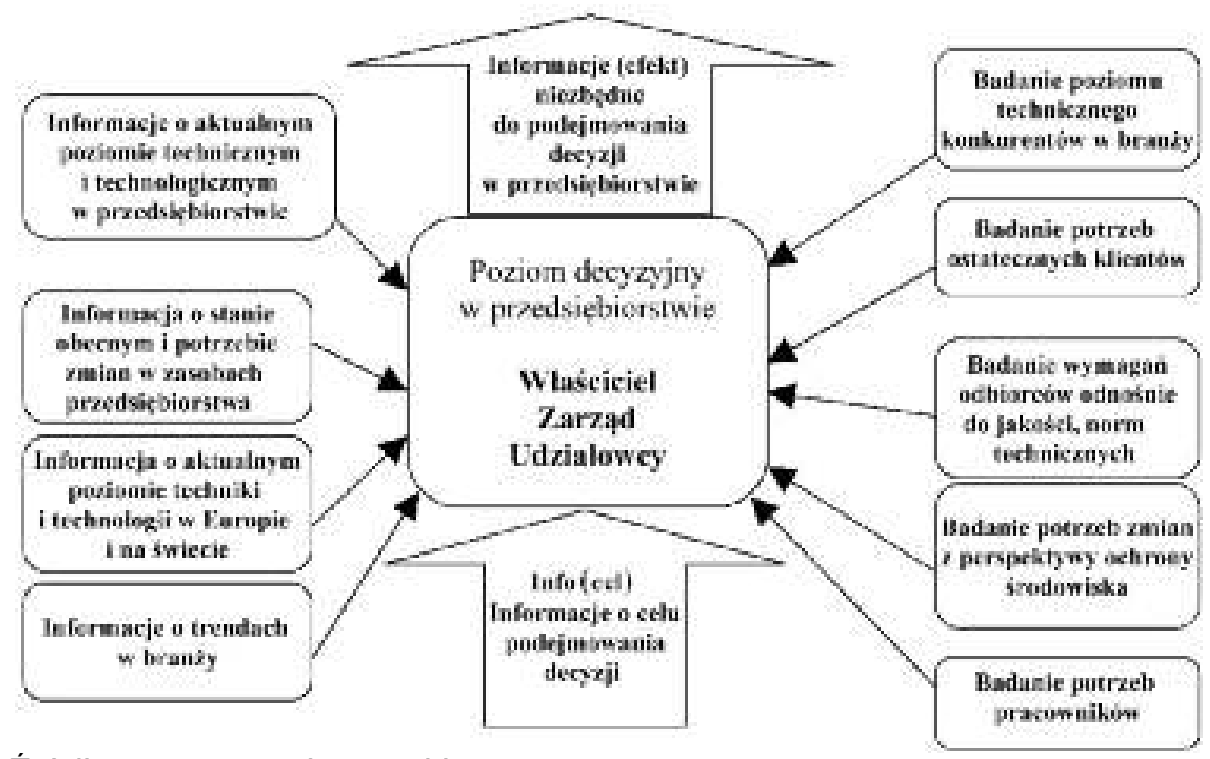

Żródło: opracowanie autorki.

Informacje, które są przekazywane do ośrodka decyzyjnego w MŚP, powinny zawierać pełne dane dotyczące otoczenia przedsiębiorstwa, konkurentów i dostawców działających w branży. Dzięki funkcjonowaniu systemu dopływu informacji do ośrodków decyzyjnych w przedsiębiorstwie proces decyzyjny opiera się na prawidłowych danych dotyczących aktualnej sytuacji rynkowej. Decyzje oparte na bieżących informacjach o rynku mogą dotyczyć:

- planowania strategii rynkowych,

- zdobywania nowych odbiorców,

- uzgadniania z klientami warunków realizacji zamówienia,

- uzyskiwania akceptacji klienta na wprowadzanie zmian i korekt w konstrukcji lub technologii wykonania czy cenie wyrobu,

- zakupu nowych urządzeń i narzędzi, materiałów i surowców,

- zwiększenia zatrudnienia,

- wyboru docelowych rynków sprzedaży,

- zmian w sposobie wynagradzania i motywowania pracowników,

- podnoszenia kwalifikacji pracowników, 
- zapoznawania się z nowoczesnymi rozwiązaniami technicznymi i technologicznymi,

- podejmowania nowych wyzwań dotyczących projektów konstrukcji metalowych, logistyki, zarządzania w firmie,

- nowych inwestycji.

Przykładem innowacyjnego wykorzystania komputerów, sieci wewnętrznej oraz internetu może być firma DiMa Sp. z o.o. w woj. łódzkim (z kapitałem duńskim). Jej specjalnością są konstrukcje stalowe spawane dla rolnictwa, budownictwa, energetyki, przemysłu stoczniowego, sprzedawane głównie na eksport. Firma istnieje od roku 2006. Jako niewielka firma od początku wybrała strategię innowacji w obszarze szybkiego dostępu do informacji i ich wykorzystania poprzez technologie informatyczne. Strategia ta miała początkowo służyć kilku menedżerom do przyspieszenia procesów decyzyjnych, ułatwienia kontaktów z kooperantami i klientami. Obecnie firma zatrudnia 60 osób, w tym 10 menadżerów, którzy mają dostęp do internetu oraz intranetu, dzięki czemu czas wymiany informacji wewnętrznych i zewnętrznych oraz proces decyzyjny są maksymalnie skrócone. W efekcie firma reaguje bardzo szybko na wszelkie sygnały płynące $\mathrm{z}$ otoczenia i na potrzeby „klientów wewnętrznych”. Jest to możliwe dzięki posługiwaniu się drugim językiem (angielskim) w kontaktach z klientami, dostawcami oraz managementem przedsiębiorstwa.

Odbiorca - lub dostawca - firmy DiMa Sp. z o.o. natychmiast otrzymuje odpowiedź na swoje pytanie. Normą w przedsiębiorstwie jest natychmiastowe reagowanie na sygnały i pytania zewnętrzne, a kontakty pomiędzy firmą a otoczeniem nie są ograniczone w jakikolwiek sposób. Obecnie firma zamierza kontynuować i rozwijać strategię innowacji poprzez powiązanie informacji zewnętrznych z procesami produkcyjnymi. Wdrażane są zintegrowany system zarządzania informacjami zewnętrznymi i wewnętrznymi oraz powiązanie wszystkich komórek organizacyjnych w ramach tego systemu. Celem strategii jest dalsze doskonalenie efektywności przedsiębiorstwa, w szerokim rozumieniu tego pojęcia.

Tego typu strategie innowacji oraz rozwiązania nie są stosowane w MŚP w Polsce, zwłaszcza w branży metalowej, a w Danii większość przedsiębiorstw z grupy MŚP opiera swoją działalność na informacji. Wdrożenie strategii innowacji tego typu w małej firmie produkcyjnej w Polsce pozwoliło na włączenie jej w struktury rynkowe na rynku europejskim oraz na rynku globalnym. Na ryc. 6 pokazano wpływ implementacji strategii innowacyjnej opartej na wykorzystaniu szybkiego przepływu informacji na wzrost obrotów w przedsiębiorstwie zagranicznym z grupy MŚP w przemyśle metalowym.

Ryc. 6. Wpływ strategii innowacyjnych opartych na elementach społeczeństwa informacyjnego na poprawę konkurencyjności przedsiębiorstwa - na przykładzie firmy DiMa Sp. z o.o.

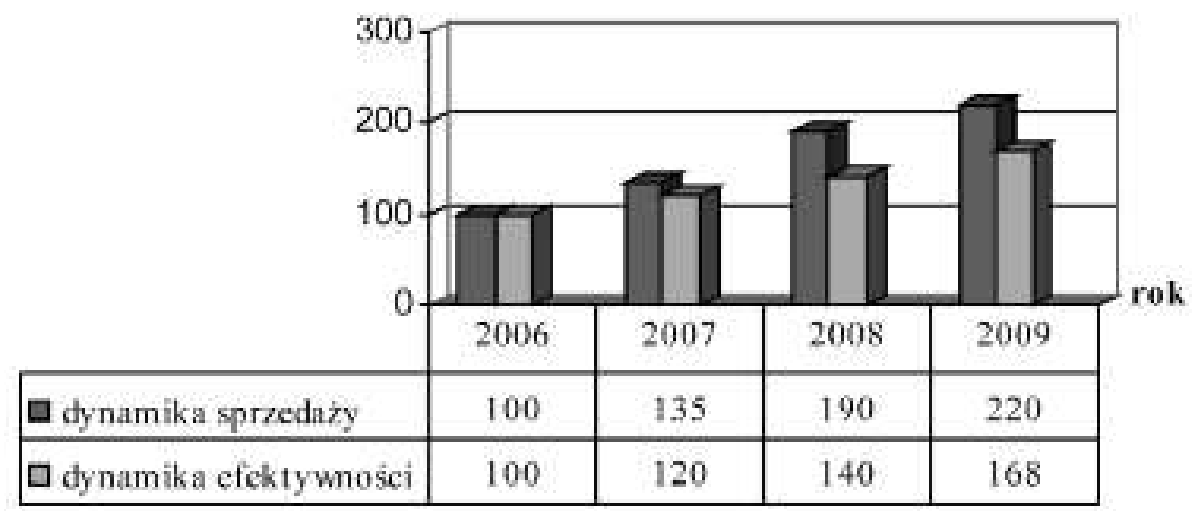

Źródło: opracowanie autorki. 
Można zatem wskazać na grupy korzyści, obecnych lub prognozowanych, jako efekty wdrażania strategii innowacyjnych opartych na atrybutach społeczeństwa informacyjnego. Oto korzyści ze strategii opartej na szybkim przepływie informacji dla przedsiębiorstw z grupy MŚP w przemyśle metalowym:

I. Korzyści rynkowe i marketingowe

- łatwość finansowania

- ułatwienia w zarządzaniu finansami przedsiębiorstwa

- wzrost efektywności zarządzania

- dostęp do rynków lokalnych i globalnych

- poprawa znajomości tych rynków - możliwość prowadzenia badań marketingowych

- zdobywanie informacji o rynku i otoczeniu przedsiębiorstwa

- możliwość prezentacji i promocji firmy i jej produktów na rynkach globalnych

- budowa wizerunku firmy

- ułatwienia w dostępie do innowacji

II. Korzyści w zakresie zasobów ludzkich

- pełne wykorzystanie kwalifikacji pracowników

- zwiększenie kwalifikacji pracowników, w tym znajomości języków obcych

- wzrost przedsiębiorczości pracowników

- wzrost kreatywności

III. Zasoby

- dostęp do zasobów wiedzy

- dostęp do zasobów z obszaru B+R

- dostęp do zasobów zaopatrzeniowych z zakresu B2B

\section{Podsumowanie}

Implementacja innowacji w zakresie przepływu informacji jest niezbędnym warunkiem podejmowania walki konkurencyjnej przez małe przedsiębiorstwa. Tworzenie baz danych przez małe przedsiębiorstwo na podstawie informacji płynących z rynku zwiększa jego wiedzę o rynku, o klientach, dostawcach, nowych technologiach i kursach walut. Rosną zatem jego szanse na utrzymanie się na rynku i podnoszenie efektywności, wzrasta jego konkurencyjność.

Na przykładzie polskiego przemysłu metalowego oraz małych firm z branży konstrukcji stalowych można wskazać korzyści, jako efekt strategii opartej na szybkim dostępie do informacji.

Jednym z kierunków zmniejszania luki technologicznej w obszarze wykorzystania technologii informacyjnych $\mathrm{w}$ zakresie podnoszenia konkurencyjności polskich przedsiębiorstw $\mathrm{z}$ grupy MŚP jest upowszechnianie zastosowania technologii i techniki informacyjnej oraz wdrażanie wszystkich atrybutów, które stanowią istotę rozwoju społeczeństwa informacyjnego.

\section{Literatura}

1. Białoń L., Janczewska D., Wiedzochłonność procesów innowacyjnych w przemyśle polskim w latach 1997-2004, „Postępy Techniki Przetwórstwa Spożywczego”, 2/2007.

2. Cele i kierunki rozwoju społeczeństwa informacyjnego $w$ Polsce, Raport, KBN, Ministerstwo Łączności, Warszawa 2000.

3. Communication from the Commission - Information Society, http://ec.europa.eu

4. Janczewska D., Podnoszenie konkurencyjności firm z grupy MŚP w branży konstrukcji spawanych, „Stal, Metale \& Nowe Technologie”, 11-12/2008.

5. Human Development Report 1990,1995, 2000, UNDP, Oxford University Press, Oxford 2001. 
6. Information Society Statistics - European Statistics Enterprises and the information Society, http://epp.eurostat.ec.europa.eu

7. Michalkiewicz A., Rozwój spoteczeństwa informacyjnego, „Bibliotekarz Warmińsko-Mazurski”, 3-4/2002.

8. Nauka i technika w Polsce w 2006 r., GUS, Warszawa 2007.

9. Perspektywy rozwoju matych i średnich przedsiębiorstw wysokich technologii w Polsce do 2020 r., E. Wojnicka (red.), Wyd. PARP, Warszawa 2006.

10. Polska $w$ drodze do globalnego społeczeństwa informacyjnego, Raport o rozwoju społecznym, Raport Narodów Zjednoczonych ds. Rozwoju UNDP, Warszawa 2002.

11. Rynek konstrukcji stalowych w Polsce. Konstrukcje stalowe, „Branżowy Informator Gospodarczy”, Warszawa, 10.12.2007 r.

12. Spoleczeństwo informacyjne w Polsce, GUS, Warszawa 2008.

13. Wykorzystanie technologii informacyjno-telekomunikacyjnej $w$ przedsiębiorstwach $w 2007$ r., GUS, Materiały publikowane z konferencji prasowej 26.11.2007 r.

\section{Application of Innovative Strategies Based on IBS (Information Based Society) to Improve the Competiveness of Company. The example of SMEs from steel industry}

One of the main goals of building the Knowledge Based Economy is building the information society. The innovations have a strong influence on this process - especially for companies that operate in most competitive environments. The factors improved the innovativeness in small companies (SME) should be explicitly accented. The example of steel industry let us identify the elements comprise the forming the information society. Then we are able to make innovation strategy to improve the competitiveness of the companies. 